\title{
PENINGKATAN KAPASITAS PERADILAN ADAT MAJELIS KUTAI DALAM PERLINDUNGAN HUTAN ADAT DESA LADANG PALEMBANG KECAMATAN LEBONG UTARA KABUPATEN LEBONG
}

\section{ENHANCEMENT OF INDIGENOUS JUDICIAL CAPACITY OF KUTAI ASSEMBLY IN INDIGENOUS FOREST PROTECTION OF LADANG PALEMBANG LEBONG DISTRICT}

\author{
Oleh: \\ M. Yamani, M. Abdi, dan Hamdani \\ Fakultas Hukum Universitas Bengkulu
}

\begin{abstract}
Local government of Ladang Palembang Lebong District has a specific way to manage village forest and protected forest nearby the village area. Forests are set in the Regulation Village, Ladang Palembang Village Regulation No. 5 of 2009 on Village Protected Forest, Indigenous Forest, and Green Area of Ladang Palembang. It contains material laws that provide sanctions for any person who violates indigenous forests and protected forests around the village of Ladang Palembang. However, to enforce the rules of material law, Kutai assembly faces a lack of procedural law or formal written law that can be used as a guide in establishing the Ladang Palembang Village Regulation No. 5 of 2009. Problem faced is a concern that skilled human resources are crisis to run Kutai assembly, which threatens the sustainability of the Kutai assembly judicial system that has been created. The method used in this society service activity is dialogical teaching, begins from focused discussion, in-depth interviews, formulate a draft model of formal legal rules of customary justice panel of Kutai, the regulation draft of the Ladang Palembang about Proceedings Technical Guidelines on Kutai Assembly Indigenous Justice of Ladang Palembang, and testing or socialization. The result of the activities is drafting of formal law model that governing the guide proceedings in the assembly Kutai, and the draft of the Ladang Palembang Village Regulation on guidelines for resolution of cases of violations involving indigenous forest of Ladang Palembang.
\end{abstract}

Key words: forest, indigenous, local law, Kutai assembly

\section{PENDAHULUAN}

Desa Ladang Palembang merupakan daerah perbukitan yang dikelilingi hutan, dengan tanah luas wilayah lebih kurang 987 hektar, berada di sekitar kawasan hutan Taman Nasinal Kerinci Sebelat (TNKS). Penduduk Desa Ladang Palembang berjumlah $226 \mathrm{KK}$ atau 834 jiwa. Kemajemukan suku bangsa yang mendiami desa Ladang Palembang tetap utuh dalam semangat kebhinekaan yang penuh kebersamaan dan toleransi. Secara geografis Desa Ladang Palembang termasuk ke dalam wilayah 
Kecamatan Lebong Utara, Kabupaten Lebong, Provinsi Bengkulu, dengan batas-batas desa sebelah Barat dengan Kabupaten Bengkulu Utara, sebelah Timur dengan Desa Lebong Tambang, sebelah Utara dengan Desa Gunung Alam, dan sebelah Selatan dengan Desa Tunggang. Adapun orbitasi, waktu tempuh dan letak desa dari ibukota Kecamatan Lebong Utara $3 \mathrm{Km}$, dari ibukota Kabupaten Lebong 4,5 Km, dan dari Ibukota Provinsi Bengkulu $250 \mathrm{Km}$ (Anonim, 2013).

Sebuah temuan penting dalam Penelitian Hibah Bersaing Tahun 2010 yang berjudul "Strategi Perlindungan Hutan pada Enam Komunitas Adat Daerah Bengkulu Sebuah Upaya Menemukan Model Pelestarian Hutan Berbasis Hukum Lokal”, yang dilakukan oleh pengusul, ialah praktik perlindungan hutan lindung, hutan adat dan kawasan penghijauan desa yang berlangsung di Desa Ladang Palembang Kecamatan Lebong Utara Kabupaten Lebong.

Pemerintah Desa Ladang Palembang sudah melakukan sebuah kebijakan publik dengan mengatur hutan lingkungan desanya dalam produk hukum lokal berupa peraturan desa, yakni Peraturan Desa Ladang Palembang Nomor 5 Tahun 2009 tentang Hutan Lindung Desa, Hutan Adat dan Kawasan Penghijauan Desa Ladang Palembang.

Pelaksana Pengabdian Pada Masyarakat Berbasis Riset menyebut ini sebuah praktik terbaik, mengingat semangat dan kepedulian aparatur desa yang begitu besar dalam melestarikan hutan. Kondisi ini bertolak belakang dengan semangat pemerintah daerah tingkat atasnya, baik provinsi maupun kabupaten, yang sampai saat ini tidak memiliki kemauan mengatur hutan dalam wilayahnya ke dalam produk peraturan daerah, melainkan menempuh cara pragmatis mengusulkan pelepasan status kawasan hutan.

Permasalahan yang dihadapi Majelis Kutai Desa Ladang Palembang yaitu belum adanya ketentuan hukum acara atau hukum formal tertulis yang dapat dijadikan sebagai pedoman dalam menegakkan Peraturan Desa Ladang Palembang Nomor 5 Tahun 2009. Aturan hukum formal yang ada sekarang ini sifatnya tidak tertulis, sehingga hanya majelis kutai saja yang menguasainya. Oleh karena itu untuk menjamin keberlanjutan praktik penegakan hukum kehutanan di desa lokasi, pemerintah Desa Ladang Palembang membutuhkan sebuah pedoman hukum formal tertulis sebagai pranata adat dalam perlindungan hutan adat.

\section{METODE PENGABDIAN}

Metode peningkatan kapasitas peradilan adat majelis kutai dalam perlindungan hutan adat Desa Ladang Palembang Kecamatan Lebong Utara Kabupaten Lebong ditempuh melalui metode-metode pembelajaran yang bersifat dialogis, dimulai dengan melakukan diskusi terfokus, sebagai pintu masuk untuk mendalami isu-isu yang berkenaan dengan objek kegiatan yang sesungguhnya sedang dihadapi oleh masyarakat khalayak sasaran. Kegiatan yang berlangsung selama diskusi terfokus, diawali dengan penjelasan 
mengenai aspek-aspek hukum materil yang memang sudah diatur dalam Peraturan Desa Ladang Palembang Nomor 5 Tahun 2009. Khalayak sasaran sebagai warga belajar atau peserta diskusi terfokus diberi waktu menanggapi substansi hukum materil yang sudah disampaikan.

Langkah selanjutnya setelah diskusi terfokus, yaitu melakukan wawancara mendalam terhadap informan kunci yang diperoleh dari diskusi terfokus. Bahan-bahan yang sudah diperoleh dari diskusi terfokus dan wawancara mendalam selanjutnya diolah dan dirumuskan dalam draft model aturan hukum formil peradilan adat majelis kutai, pelaksana menawarkan kepada peserta diskusi ruang lingkup materi muatan yang akan diatur dalam pedoman aturan formil, point-pont yang mendapat kesepakatan dari peserta diskusi/khalayak sasaran selanjutnya dicatat dan dijadikan materi muatan pedoman sidang peradilan adat majelis kutai yang akan dibentuk. Pedoman beracara yang sudah dirumuskan, sebelum ditetapkan menjadi draft final, terlebih dahulu diujicoba, dengan mengadakan metode simulasi peradilan adat majelis kutai semu, dan seterusnya dimutakhirkan, hingga sempurna, kemudian dituangkan ke dalam draft Peraturan Desa Ladang Palembang tentang Pedoman Teknis Beracara pada Peradilan Adat Majelis Kutai Desa Ladang Palembang.

\section{HASIL DAN PEMBAHASAN}

\section{Hutan di Kabupaten Lebong}

Kabupaten Lebong memiliki wilayah seluas $192.924 \mathrm{Ha}$, hampir $70 \%$ wilayahnya merupakan kawasan hutan, terdiri atas hutan lindung seluas 20.777,40 Ha (10,76 persen), Taman Nasional Kerinci Seblat (TKNS) 109.548 Ha (57,55 \%) dan Suaka Alam 3.022,15 Ha $(1,56 \%)$, sisanya $(30,10 \%)$ atau $58.089,45$ Ha merupakan areal pemukiman dan peruntukan lainnya. Namun pada saat ini laju kerusakan hutan lindung yang ada di Kabupaten Lebong terus meningkat, sampai saat ini sudah mencapai 40 persen $(54.000$ Ha) dari kawasan hutan seluruhnya tercatat 134.845 Ha. Kerusakan kawasan hutan itu terdiri atas hutan cagar alam, hutan lindung dan TNKS, kerusakan itu antara lain akibat perambahan masyarakat dan pencurian kayu (Anonim, 2008). Kabupaten Lebong telah dipilih oleh pemerintah untuk ditetapkan statusnya sebagai "Kabupaten Konservasi" yang berbasis lingkungan dan penyelamatan hutan (Sari, 2009).

\section{Hutan Di Desa Ladang Palembang}

Desa Ladang Palembang memiliki hutan adat, yang berasal dari APL Tik Gelung seluas 15 hektar, sebagian TNKS dan APL Air Semiep seluas 65 hektar, dan kawasan TNKS Sarang Macam seluas 20 hektar.

Hutan lindung Tik Gelung berjarak $1 \mathrm{~km}$ dari pusat Desa Ladang Palembang, yang merupakan sumber air utama bagi kebutuhan sehari-hari masyarakat setempat dan desa 
sekitarnya. Mengingat pohon dan tumbuhan lainnya yang terdapat di kawasan hutan tersebut berperan penting dalam menjaga kestabilan mata air, maka harus dilestarikan (Pemerintah Kabupaten Lebong, 2009).

Hutan lindung desa Bukit Sarang Macan, berjarak $6 \mathrm{~km}$ dari wilayah desa, ditetapkan sebagai kawasan perlindungan desa mengingat peran pentingnya dalam menjaga kelangsungan sumber mata air Udik dan Tik Gelung yang melintasi kawasan transmigrasi Ladang Palembang yang digunakan untuk kebutuhan rumah tangga dan pertanian.

Hutan adat desa Air Semiep, terletak 7,5 km dari desa, yang berada di sepanjang sungai Semiep yang sebagian besar sudah diolah oleh masyarakat menjadi kebun dan sudah ditanami dengan berbagai jenis tanaman. Wilayah ini merupakan areal sisa yang belum dibuka menjadi lahan perkebunan disepakati untuk dilindungi guna menjaga keseimbangan tanah di sekitar sungai yang memiliki kecuraman tinggi dan uneuk menjaga kelestarian hayati.

\section{Kebijakan Pemerintah Kabupaten Lebong dalam Perlindungan Hutan}

Kebijakan penting yang dilakukan Pemerintah Kabupaten Lebong dalam perlindungan hutan, antara lain pembentukan tim pemangku kawasan hutan yang diatur dalam Keputusan Bupati Lebong Nomor 642 Tahun 2009 tentang Penunjukan Tim Pemangku Hutan Di Kabupaten Lebong. Kebijakan tersebut menetapkan Kepala Desa sebagai Tim Pemangku Hutan yang ditempatkan di desa mereka masing-masing untuk menjaga dan melestarikan hutan yang ada di desa mereka.

Penguatan kelembagaan Tim Pemangku Kawasan Hutan tersebut dilakukan dengan membentuk Peraturan Daerah Nomor 11 Tahun 2010 tentang Kepala Desa Sebagai Pemangku Kawasan Hutan, yang diberi tugas (a) mengamankan hutan di desanya dari setiap adanya ganguan keamanan terhadap kawasan hutan dan hasil hutan yang disebabkan oleh perbuatan manusia, ternak, kebakaran, dan lainnya; (b) membentuk kelompok kerja pengamanan hutan di desa; (c) membuat peta wilayah desa yang di dalamnya tercakup kawasan hutan; (d) menginventarisasi warganya baik tetap maupun pendatang yang menggarap hutan; (e) bersama-sama dengan aparat kehutanan memberikan informasi dan penyuluhan kepada masyrakat tentang kawasan hutan; (f) melarang warga/ pendatang yang menggarap kawasan hutan negara; dan (g) melapor kepada camat dengan tembusan kepada dinas apabila terjadi perambahan dan pengrusakan hutan. Kebijakan tersebut sangat sejalan dengan rencana menetapkan Kabupaten Lebong sebagai Kabupaten Konservasi.

\section{Kebijakan Pemerintah Desa Ladang Palembang dalam Perlindungan Hutan}

Pemerintah Desa Ladang Palembang sebagai bagian dari Pemerintah Kabupaten Lebong, sudah melakukan terobosan penting dengan menerapkan kebijakan desa di bidang perlindungan hutan, yakni dengan membentuk Peraturan Desa Ladang Palembang Nomor 5 Tahun 2009 tentang Hutan Lindung Desa, Hutan Adat dan Kawasan Penghijauan Desa 
Ladang Palembang. Kebijakan desa tersebut didasarkan atas kesepakatan bersama masyarakat dan pemerintah desa untuk melakukan pengelolaan sumberdaya alam secara berencana. Berkenaan dengan kewenangan mengelola kawasan hutan, diatur dalam Pasal 1 huruf j yang menentukan "Kelompok Tani Penghijauan (KTP) adalah sebuah kelembagaan desa yang bertugas mengelola kawasan hutan lindung dan hutan adat desa".

Berkenaan dengan lembaga peradilan adat yang disebut "majelis kutai" sebagai lembaga yudikatif yang berwenang mengadili pelanggaran di bidang kehutanan. Secara garis besarnya Pasal 18 Peraturan Desa Ladang Palembang Nomor 5 Tahun 2009, mengatur, apabila dalam proses awal terdapat cukup bukti bahwa seseorang diduga telah melakukan pelanggaran menyangkut hutan, maka pemerintah desa meneruskannya dengan meminta majelis kutai melaksanakan sidang disertai dengan berkas pemeriksaan awal. Majelis kutai atau tiga suku panembahan terdiri atas kepala adat, kepala kutai dan ketua syara' melaksanakan sidang adat yang terbuka untuk masyarakat.

Penetapan sanksi dilakukan dengan cara musyawarah oleh majelis kutai setelah mendengarkan keterangan-keterangan saksi yang meringankan (a decharge) pelanggar yang diberikan oleh pihak keluarga pelanggar. Jika si pelanggar tidak mau menjalankan putusan yang dijatuhkan majelis kutai, maka perkaranya diserahkan ke aparat hukum negara untuk diproses berdasarkan hukum negara, dengan sedapat mungkin menjadikan keputusan majelis kutai sebagai pertimbangan dalam menetapkan keputusan.

Tabel 1. Sanksi Pelanggaran Terhadap Peraturan Desa Ladang Palembang Tentang Hutan Lindung Desa, Hutan Adat dan Kawasan Penghijauan Desa Ladang Palembang

\begin{tabular}{|c|c|c|c|}
\hline \multirow{2}{*}{ Pasal } & \multirow{2}{*}{ Jenis Pelanggaran } & \multicolumn{2}{|c|}{ Bentuk Sanksi } \\
\hline & & Adat & Denda \\
\hline $10(1)$ & $\begin{array}{l}\text { Mengambil buah-buahan hutan, tanaman obat } \\
\text { dan madu dengan cara menebang pohon }\end{array}$ & $\begin{array}{ll}\checkmark & \text { masak serawo. } \\
\checkmark & \text { punjung kambing } \\
\checkmark & \text { beras } 2 \text { kaleng }\end{array}$ & $\begin{array}{l}\checkmark \text { seharga pohon yang } \\
\text { ditebang }\end{array}$ \\
\hline $10(2)$ & $\begin{array}{l}\text { Melakukan pembakaran ladang yang } \\
\text { berbatasan langsung dengan lahan kritis hutan } \\
\text { desa tanpa membuat parit }\end{array}$ & $\begin{array}{ll}\checkmark & \text { masak serawo } \\
\checkmark & \text { punjung ayam } \\
\checkmark & \text { beras } 2 \text { kaleng }\end{array}$ & $\begin{array}{l}\checkmark \text { seharga pohon yang } \\
\quad \text { ditebang }\end{array}$ \\
\hline $10(3)$ & $\begin{array}{l}\text { Pemilik kebun berbatasan langsung dengan } \\
\text { lahan kritis hutan desa tidak menanami } \\
\text { tanaman penghijauan }\end{array}$ & $\begin{array}{ll}\checkmark & \text { Masak serawo } \\
\checkmark & \text { punjung ayam } \\
\checkmark & \text { beras } 2 \text { kaleng }\end{array}$ & \\
\hline $11(1)$ & $\begin{array}{l}\text { Membuka perluasan kebun dalam kawasan } \\
\text { hutan lindung desa Tik Gelung dan Bukit } \\
\text { Sarang Macan }\end{array}$ & $\begin{array}{ll}\checkmark & \text { masak serawo } \\
\checkmark & \text { punjung kambing } \\
\checkmark & \text { beras } 2 \text { kaleng }\end{array}$ & $\begin{array}{ll}\checkmark & \text { seharga pohon yang } \\
& \text { ditebang } \\
\checkmark & \text { mengembali } \\
& \text { kan lahan ke batas } \\
& \text { semula }\end{array}$ \\
\hline $11(2)$ & $\begin{array}{l}\text { Pemilik kebun dalam kawasan hutan tik } \\
\text { gelung tidak menanam tanaman tua dan tidak } \\
\text { menjaga kelestariannya }\end{array}$ & $\begin{array}{ll}\checkmark & \text { masak serawo } \\
\checkmark & \text { punjung ayam } \\
\checkmark & \text { beras } 2 \text { kaleng }\end{array}$ & \\
\hline $12(1)$ & $\begin{array}{l}\text { Mengambil pohon sialang dan buah hutan } \\
\text { dengan cara menebang }\end{array}$ & $\begin{array}{ll}\checkmark & \text { masak serawo } \\
\checkmark & \text { punjung kambing } \\
\checkmark & \text { beras } 2 \text { kaleng }\end{array}$ & $\begin{array}{l}\checkmark \text { seharga pohon yang } \\
\text { ditebang atau } \\
\text { dirusak }\end{array}$ \\
\hline
\end{tabular}




\begin{tabular}{|c|c|c|c|c|c|}
\hline $12(2)$ & $\begin{array}{l}\text { Tidak memberikan sumbangan desa dari } \\
\text { panen pohon sialang }\end{array}$ & $\checkmark$ & $\begin{array}{l}\text { masak serawo } \\
\text { punjung ayam } \\
\text { beras } 2 \text { kaleng }\end{array}$ & $\checkmark$ & $\begin{array}{l}\text { membayar } \\
\text { sumbangan desa }\end{array}$ \\
\hline $13(1)$ & $\begin{array}{l}\text { Membuka hutan adat desa untuk perluasan } \\
\text { kebun baru }\end{array}$ & $\begin{array}{l}\checkmark \\
\checkmark \\
\checkmark\end{array}$ & $\begin{array}{l}\text { masak serawo } \\
\text { punjung kambing } \\
\text { beras } 2 \mathrm{klg}\end{array}$ & $\checkmark$ & $\begin{array}{l}\text { seharga pohon yang } \\
\text { ditebang atau } \\
\text { dirusak }\end{array}$ \\
\hline $13(2)$ & $\begin{array}{l}\text { Tidak menanami hutan adat desa dengan } \\
\text { tanaman tua/kayu-kayuan }\end{array}$ & $\begin{array}{l}\checkmark \\
\checkmark \\
\checkmark\end{array}$ & $\begin{array}{l}\text { masak serawo } \\
\text { punjung ayam } \\
\text { beras } 2 \mathrm{klg}\end{array}$ & & \\
\hline $14(1)$ & $\begin{array}{l}\text { Mengambil ikan dengan racun, setrum di } \\
\text { sepanjang aliran sungai Semiep }\end{array}$ & $\begin{array}{l}\checkmark \\
\checkmark \\
\checkmark\end{array}$ & $\begin{array}{l}\text { masak serawo } \\
\text { punjung kambing } \\
\text { beras } 2 \mathrm{klg}\end{array}$ & $\checkmark$ & $\begin{array}{l}\text { 1/2 bangun setara } \\
\text { Rp2juta } \\
\text { Melepas bibit ikan } \\
\text { sejumlah yg } \\
\text { ditangkap }\end{array}$ \\
\hline $14(2)$ & $\begin{array}{l}\text { Meracun, menstrum, ikan sepanjang sungai } \\
\text { Semiep yang mengakibatkan kematian pada } \\
\text { manusia }\end{array}$ & & & $\checkmark$ & $\begin{array}{l}1 \text { bangun yaitu } 80 \\
\text { real setara dgn } \operatorname{Rp} 8 \\
\text { juta }\end{array}$ \\
\hline $14(3)$ & $\begin{array}{l}\text { Meracun, strum ikan sepanjang sungai Semiep } \\
\text { yang mengakibatkan kematian pada ternak }\end{array}$ & & & $\checkmark$ & $\begin{array}{l}\text { ganti rugi senilai } \\
\text { ternak yang mati }\end{array}$ \\
\hline $15(1)$ & $\begin{array}{l}\text { Menebang tanaman tua tidak produktif tanpa } \\
\text { izin }\end{array}$ & $\begin{array}{l}\checkmark \\
\checkmark \\
\checkmark\end{array}$ & $\begin{array}{l}\text { masak serawo } \\
\text { punjung kambing } \\
\text { beras } 2 \text { kaleng }\end{array}$ & $\checkmark$ & $\begin{array}{l}\text { senilai harga pohon } \\
\text { yang ditebang }\end{array}$ \\
\hline $15(2)$ & $\begin{array}{l}\text { Pejabat memberi izin menebang tanaman } \\
\text { tidak produktif yang tanaman penggantinya } \\
\text { belum berumur } 6 \text { bulan }\end{array}$ & $\checkmark$ & $\begin{array}{l}\text { masak serawo } \\
\text { punjung kambing } \\
\text { beras } 2 \text { kaleng }\end{array}$ & $\checkmark$ & $\begin{array}{l}\text { senilai harga pohon } \\
\text { yang ditebang }\end{array}$ \\
\hline $16(1)$ & $\begin{array}{l}\text { Menebang pohon dalam kawasan penghijauan } \\
\text { desa tanpa izin pengurus KTP }\end{array}$ & $\checkmark$ & $\begin{array}{l}\text { masak serawo } \\
\text { punjung ayam } \\
\text { beras } 2 \text { kaleng }\end{array}$ & $\checkmark$ & $\begin{array}{l}\text { menanam tanaman } \\
\text { pengganti }\end{array}$ \\
\hline $16(2)$ & $\begin{array}{l}\text { KTP memberi izin penebangan tanpa } \\
\text { mensyaratkan penebang menanam pohon } \\
\text { pengganti dan belum berumur } 6 \text { bulan }\end{array}$ & $\checkmark$ & $\begin{array}{l}\text { masak serawo } \\
\text { punjung ayam } \\
\text { beras } 2 \text { kaleng }\end{array}$ & $\checkmark$ & $\begin{array}{l}\text { menanam kembali } \\
\text { tanaman pengganti. } \\
\text { Membayar senilai } \\
\text { harga pohon yang } \\
\text { Ditebang }\end{array}$ \\
\hline $17(1)$ & $\begin{array}{l}\text { Kewajiban menanam pohon di jalan desa atau } \\
\text { tanah desa. } \\
\text { Kewajiban gotong royong menanam tanaman } \\
\text { di jalan desa }\end{array}$ & $\checkmark$ & $\begin{array}{l}\text { masak serawo } \\
\text { punjung ayam } \\
\text { beras } 2 \text { kaleng }\end{array}$ & $\checkmark$ & membayar denda \\
\hline $17(2)$ & $\begin{array}{l}\text { Kewjiban menanam pohon di pekarangan } \\
\text { rumah minimal } 3 \text { batang }\end{array}$ & & $\begin{array}{l}\text { Wajib menanam } \\
\text { tanaman di jalan desa }\end{array}$ & & \\
\hline
\end{tabular}

Sumber: Peraturan Desa Ladang Palembang Nomor 5 Tahun 2009

Kesemua bentuk sanksi dan nilai denda adat atas pelanggaran hutan adat desa diserahkan ke desa untuk diteruskan kepada pemilik lahan sebesar 50\%, kas desa 25\% dan kepada kelompok tani penghijauan sebesar $25 \%$ untuk dijadikan biaya rehabilitasi hutan adat. Kebijakan yang ditempuh pemerintah desa Ladang Palembang tersebut tampaknya diilhami oleh hukum lokal era undang-undang simbur cahaya, yang mengenal aturan partisipasi warga komunitas adat dalam penjagaan hutan yang disebut ngubungi gawai, 
yakni melaporkan adanya peristiwa pelanggaran atas hutan adat kepada aparatur desa. Disamping itu, dihidupkannya kembali lembaga peradilan asli yang era pemerintahan marga umumnya dikenal dengan rembuk tuei kutei, atau yang di daerah komunitas adat Rejang dewasa ini disebut dengan istilah jenang kutei atau majelis kutai, tampaknya diadopsi kembali ke dalam sistem penyelesaian pelanggaran hutan lindung di Desa Ladang Palembang (Abdi, 2000).

Berkenaan dengan sanksi pelanggaran aturan hutan lindung desa, tampaknya produk hukum lokal ini mengadopsi bentuk sanksi adat asli komunitas Rejang sekaligus sanksi denda pengaruh Undang-Undang Simbur Cahaya Bengkulu sebagaimana diuraikan dalam Tabel 1 di atas.

\section{Desa Ladang Palembang sebagai Masyarakat Hukum Adat}

Masyarakat hukum adat atau persekutuan hukum adat (adatrechtsgemeneschap) adalah kesatuan manusia yang teratur, menetap di suatu daerah tertentu, mempunyai penguasa-penguasa, dan mempunyai kekayaan yang berwujud ataupun tidak berwujud, di mana para anggota kesatuan masing-masing mengalami kehidupan dalam masyarakat sebagai hal yang wajar menurut kodrat alam dan tidak seorang pun di antara para anggota itu mempunyai fikiran atau kecenderungan untuk membubarkaan ikatan yang telah tumbuh itu atau meninggalkannya dalam arti melepaskan diri dari ikatan itu untuk selama-lamanya (Bushar, 1976).

Setiap masyarakat hukum adat memuat dalam strukturnya unsur-unsur keturunan (geneologis) atau mempunyai suatu struktur yang sifatnya teritorial geneologis (dalam hal unsur-unsur teritorial lebih kuat daripada unsur geneologis) atau mempunyai struktur yang sifatnya geneologis teritorial (dalam hal unsur geneologis lebih kuat daripada teritorial). Masyarakat hukum adat yang sifatnya teritorial yaitu masyarakat hukum adat yang disusun berasaskan lingkungan daerah, di mana para anggotanya merasa bersatu, karena adanya ikatan antara mereka masing-masing dengan tanah tempat tinggal mereka. Landasan yang mempersatukan para anggota masyarakat hukum adat yang strukturnya bersifat teritorial adalah ikatan antara orang dengan tanah yang didiaminya sejak kelahirannya secara turun temurun. Ikatan dengan tanah menjadi inti asas teritorial, sehingga dalam konteks ini kemudian dikenal masyarakat hukum desa, masyarakat hukum wilayah dan masyarakat hukum serikat desa. Masyarakat Desa Ladang Palembang merupakan contoh masyarakat hukum adat yang bersifat territorial.

\section{Perumusan Norma Hukum Formil sebagai Pedoman Majelis Kutai dalam} Menegakkan Hukum Materil Lokal Perlindungan Hutan di Desa Ladang Palembang

Hukum lokal komunitas adat Ladang Palembang menempatkan status hukum kepemilikan hutan sebagai hak milik komunal setiap masyarakat hukum adat, dengan pergeseran nilai, dari semula memandang hutan dapat dikuasai dan dimiliki dengan bebas oleh setiap individu warga masyarakat hukum adat, menjadi penguasaan yang 
bertanggungjawab, dengan dirumuskannya tatanan nilai dan norma hukum lokal yang disepakati bersama, yang membatasi pemanfaatan dan penguasaan hutan.

Kesepakatan bersama masyarakat Desa Ladang Palembang dalam merumuskan sistem norma hukum lokal materil dan formil di bidang perlindungan hutan, didasarkan atas kesadaran kesamaan kebutuhan akan fungsi hutan sebagai penyangga sistem kehidupan bersama desa. Materi muatan aturan lokal materil meliputi aturan berkenaan dengan kategori hutan yang boleh diusahakan, tabu atau larangan menyangkut hutan, dan sanksi adat sebagai reaksi dilanggarnya aturan materil. Aspek perbuatan yang dilarang berdasarkan materi muatan hukum lokal materil tersebut, menunjukkan sejak lama komunitas adat sudah memiliki sistem norma tidak tertulis yang menjadi hukum positif kala itu, sebagai instrumen dalam pengelolaan hutan, yang mencerminkan kekhawatiran rusaknya hutan yang dianggap sebagai bagian dari sistem penyangga kehidupan masyarakat tradisional, baik secara ekonomis maupun ekologis. Setiap komunitas adat berpendirian rusaknya hutan mengancam keberlanjutan hidup manusia.

Berkenaan dengan jenis sanksi dalam hukum adat Rejang dapat dikelompokkan ke dalam dua jenis sanksi, yaitu pertama, sanksi adat permintaan maaf kepada sesama warga masyarakat hukum adat dan kepada kekuatan ghaib yang terganggu akibat pelanggaran atas larangan yang sudah disepakati dalam aturan hukum kehutanan lokal. Bentuk konkrit sanksi adat permintaan maaf berupa punjung kambing atau ayam, beras, dan sebagainya, yang ditetapkan melalui musyawarah adat yang dikenal dengan sebutan majelis kutai. Kedua, sanksi denda adat menanam pohon pengganti, diterapkan terhadap pelanggaran atas larangan menebang pohon tanpa izin, membuka hutan tanpa izin, menebang pohon di sembarang lokasi, menebang pohon langka dengan fungsi pengobatan, dan memanen madu sialang dengan cara menebang pohon (Yamani dan Kusmito, 2010).

Penerapan sanksi menanam pohon pengganti, setiap orang yang bersalah menebang satu pohon, kepadanya jatuh sanksi wajib menanam pohon pengganti, paling sedikit enam pohon dan paling banyak sepuluh pohon dan memeliharanya sampai berumur enam bulan atau memiliki daya tahan hidup. Aturan materil lokal dalam bentuk asli, tidak mengenal sanksi adat berbentuk sejumlah uang. Penerapan jenis sanksi denda sejumlah uang ini berasal dari pengaruh kolonial yang menyeragamkan sistem hukum lokal komunitas adat daerah Bengkulu dalam produk undang-undang simbur cahaya Bengkulu.

Materi muatan hukum lokal yang termasuk kategori aturan formil (hukum acara) sebagai pedoman bagi majelis kutai dalam menegakkan aturan hukum materil yang sudah diatur dalam Perdes Ladang Palembang Nomor 5 Tahun 2009, masih sangat sederhana, justru inilah yang menjadi pusat perhatian pengabdian pada masyarakat ini. Ketentuan Pasal 18 ayat (1) Perdes Ladang Palembang Nomor 5 Tahun 2009, mengatur mekanisme penjatuhan sanksi, yang pada hakikatnya mengandung unsur hukum acara, ketentuan dimaksud berbunyi, "dalam hal diketahui terjadinya pelanggaran karena adanya laporan, maka pemerintah desa dalam hal ini kepala desa beserta perangkat desa melaksanakan proses awal untuk membuktikan benar atau tidaknya pelanggaran tersebut." Patut diberi 
garis bawah pada frase kata "proses awal". Apakah sama dengan pemeriksaan pendahuluan dalam Hukum Acara Peradilan Tata Usaha Negara, atau proses penyelidikan sebagaimana dalam Hukum Acara Pidana. Jika dikaitkan dengan ketentuan ayat (3) yang berbunyi "Bila dalam proses awal tersebut terbukti pelakunya telah melakukan pelanggaran, maka pemerintah desa meneruskan dengan meminta Majelis Kutai melaksanakan sidang disertai dengan berkas pemeriksaan awal," maka jelas hakikat proses awal sama dengan penyeledikan dan penyidikan.

Pada ketentuan ayat (4) ditentukan bahwa "Majelis kutai atau suku penembahan terdiri dari kepala adat, kutai dan syara' melaksanakan sidang adat yang terbuka untuk masyarakat". Selanjutnya pada ayat (5) ditentukan pula bahwa "Penetapan sanksi dilakukan dengan cara musyawarah oleh Majelis Kutai setelah mendengar keteranganketerangan yang meringankan pelanggaran yang diberikan oleh pihak keluarga pelanggar." Apabila dikaitkan dengan sistem hukum acara, tampak jelas bahwa hakikat musyawarah majelis kutai memiliki kesamaan dengan mekanisme bekerjanya sebuah peradilan dalam hukum positif. Oleh karena itu, maka dalam draft hukum acara yang dirumuskan, mengadopsi model-model hukum acara positif, dengan menyesuaikan dengan kebutuhan musyawarah adat majelis kutai.

Pada tingkap proses awal atau pemeriksaan awal untuk pemberkasan perkara yang dilakukan oleh kepala desa dan perangkat desa, dirumuskan beberapa ketentuan hukum acara sesuai hasil diskusi terfokus, yaitu, berkenaan dengan administrasi proses awal, dipertegas antara lain dengan mengatur soal-soal, pertama, surat panggilan kepada pelaku sesuai dengan laporan masyarakat, kewenangan memanggil/menandatangani surat panggilan, bentuk surat panggilan, petugas yang menyampaikan surat panggilan, frekuensi panggilan, bukti penerimaan surat panggilan, dan sanksi dalam hal terlapor tidak memenuhi panggilan. Kedua, mekanisme pemeriksaan awal atau penyelidikan/penyidikan, antara lain mengatur pemeriksaan secara terbuka atau tertutup, jumlah tim pemeriksa terlapor, tempat pemeriksaan, berita acara pemeriksaan, pendampingan hukum bagi terlapor, jumlah saksi minimal yang diperlukan, dan berita acara pemeriksaan terlapor, dan pelimpahan berkas perkara ke majelis kutai.

Pada tingkat persidangan musyawarah adat dalam lembaga majelis kutai, dirumuskan ketentuan hukum acara sesuai hasil diskusi terfokus, yaitu, pertama, berkenaan dengan persiapan persidangan musyawarah adat, antara lain administrasi penetapan hari dan tanggal sidang, pemanggilan pihak-pihak (terlapor, saksi-saksi), kedua, berkenaan dengan mekanisme sidang majelis kutai, dirumuskan ketentuan tata cara pembukaan sidang, penggunaan palu, bentuk dakwaan, mekanisme pemeriksaan keterangan saksi, keterangan terlapor/tertuduh, proses jawab menjawab (penuntutan, pembelaan, replik dan duplik), mekanisme pengambilan putusan majelis kutai, dan jenis putusan majelis kutai. Ketiga, berkenaan dengan pelaksanaan putusan majelis kutai, diatur soal-soal pemegang wewenang melaksanakan putusan majelis kutai, dan prosedur upacara pelaksanaan putusan majelis kutai. 


\section{KESIMPULAN}

Dari hasil dan pembahasan dapat ditarik beberapa kesimpulan, diantaranya:

1. Desa Ladang Palembang sebagai kesatuan masyarakat hukum adat yang bersifat territorial sudah memiliki aturan hukum acara dalam menegakkan hukum kehutanan materil, namun belum semuanya dirumuskan secara terperinci dalam naskah tertulis, dan fokus pengabdian pada masyarakat yang dilakukan ini mengupayakan merumuskan secara lengkap dan rinci ketentuan hukum acara sidang majelis kutai Desa Ladang Palembang.

2. Perumusan naskah hukum acara dilakukan dengan menggunakan pendekatan perbandingan dengan hukum acara yang berlaku dalam sistem peradilan pidana, dan pendekatan historis dengan mengadopsi praktik penyelesaian pelanggaran hukum adat yang pernah berlaku dalam komunitas adat Rejang, khususnya di wilayah Kabupaten Lebong, dan dokumen Undang-Undang Simbur Cahaya Bengkulu.

\section{DAFTAR PUSTAKA}

Anonim, 2013, Monografi Desa Ladang Palembang Kecamatan Lebong Utara Tahun.

Anonim, 2008, Lebong Akan Berlakukan Hukum Adat Atasi Kerusakan Hutan, www.antara.co.id, Jakarta, Diakses hari Jumat, 23 September 2013, 14.00 WIB.

Bushar Muhammad, 1976, Asas-asas Hukum Adat (Suatu Pengantar), Jakarta: Pradnya Paramita.

Abdi, M., 2000, Peranan Lembaga Adat Tradisional masayarakat Rejang (Kutei) dalam Penyelesaian Tindak Pidana, Semarang: Thesis Pascasarjana Ilmu Hukum Universitas Diponegoro.

Yamani, M., dan Kusmito Gunawan, 2010, Strategi Perlindungan Hutan pada Enam Komunitas Adat Daerah Bengkulu Sebuah Upaya Menemukan Model Pelestarian Hutan Berbasis Hukum Lokal, Lemlit Unib: Laporan Hasil Penelitian Hibah Bersaing Tahun ke-2 Tahun Anggaran 2010.

Pemerintah Kabupaten Lebong, 2009, Pengukuhan Kawasan Hutan Menjadi Hutan Adat Desa Ladang Palembang, Tubei: Dinas Kehutanan.

Peraturan Desa Ladang Palembang Nomor 5 Tahun 2009 Pasal 17.

Sari Ria Permata, 2009, Kebijakan Pemerintah Daerah Kabupaten Lebong Dalam Melestarikan Hutan Lindung Taman Nasional Kerinci Seblat (TNKS)", Skripsi, S1 FH Unib. 